\title{
Bağcılıkta İyi Tarım Uygulamaları Hakkında Üreticilerin Bilgi Düzeyinin İncelenmesi: Manisa İli, Salihli İlçesi Araştırması
}

\author{
Özlem Alemdar $^{1} \quad$ Murat Akkurt $^{1 *}$
}

Yener Ataseven ${ }^{2}$

${ }^{1}$ Ankara Üniversitesi Ziraat Fakültesi Bahçe Bitkileri Bölümü, Ankara
${ }^{2}$ Ankara Üniversitesi Ziraat Fakültesi Tarım Ekonomisi Bölümü, Ankara
${ }^{*}$ Sorumlu Yazar: akkurt@agri.ankara.edu.tr

Geliş Tarihi: 24.05.2019

Kabul Tarihi: 28.06.2019

\section{$\ddot{O} \mathbf{z}$}

Araştırmada Manisa ili Salihli ilçesi örneğinde, bağcılıkta İyi Tarım Uygulamaları (ITTU)' da etkili olan faktörlerin belirlenmesi ve İTU teknikleri hakkında üreticilerin temel bilgi düzeyinin incelenmesi amaçlanmıştır. Bu doğrultuda, Manisa ili Salihli ilçesi, Merkez, Kemerdamları, Poyrazdamları, Adala, Çapaklı, Bektaşlar, Durasıllı, Pazarköy, Çökelek, Süleymaniye, Kabazlı ve Mersinli mahallelerinde anket çalışmaları yapılmıştır. Örnekleme yöntemi olarak "Oransal Örnek Hacmi” formülü kullanılmıştır ve \%99 güven aralığı ve \%10 hata payı dikkate alınarak toplam 80 üretici ile yüz yüze görüşülmüştür. Çalışma kapsamında, üreticilerin demografik özellikleri, bağcılıkta İTU teknikleri hakkındaki bilgi düzeyi, üreticilerin İTU'dan memnuniyet durumu, karşılaşılan problemler, sunulan çözüm önerileri ve İTU'nun geleceği hakkındaki düşünceler incelenmiştir. Araştırma bulgularına göre, bölgede İTU yapan üreticilerin bilgi düzeylerinin genel olarak yeterli olduğu görülmüsşür. Üreticilerin önemli bir kısmı İTU standardının öneminin giderek artacağını, İTU'nun tarımsal destekler ile daha da gelişebileceği ve yaygınlaşabileceğini belirtmişlerdir. Bununla birlikte, üzüm yetiştiriciliğinde hastalık ve zararlı mücadelesi konusunda üreticilerin ilk olarak kimyasal mücadele yöntemine başvurması entegre mücadele yöntemlerine hakim olmadıkları sonucunu ortaya çıkarmıştır. İlaçlama konusu, önemli risklerden biri olup, üreticilerin ilaçlama yaparken koruyucu ekipman kullanma konusunda yeteri kadar duyarlı olmadıkları görülmüştür.

Anahtar kelimeler: Ege Bölgesi, Bağcılık, Anket çalışması

\section{Examination of the Producers Knowledge Level about Good Agricultural Practices: An Example of Manisa/Salihli}

\section{Abstract}

It is aimed determination of factors affects Good Agricultural Practices (GAP) in viticulture and examining basic knowledge of producers about GAP techniques with this study at Manisa city, Salihli county. According to this survey carried out at Manisa City, Salihli County, Centre, Kemerdamları, Poyrazdamları, Adala, Çapaklı, Bektaşlar, Durasıllı, Pazarköy, Çökelek, Süleymaniye, Kabazlı and Mersinli districts. "Proportional Sample Volume" formula was used as the sampling method and a total of 80 producers were interviewed face-to-face considering the $99 \%$ confidence interval and $10 \%$ error margin. It is examined with surveys on individual characteristics of producers, knowledge about GAP in viticulture, satisfaction with good agricultural practices, problems encountered, suggestions about solutions and the future of good agricultural practices due to study scope. According to research findings, it is seen knowledge level of the producers who carries out good agriculture practices are generally sufficient at region. A major part of viticulturists who carries GAP indicates that 'standards of GAP will be more important and GAP can be improved and become widespread with agricultural supports'. However it is concluded, producers are not well informed of integrated pest and disease management because they apply chemical management methods first. Agricultural spraying subject is one of the major risks but it is seen producers are not caring enough about using protective equipment when they are agricultural spraying. According to these conclusions it shows up to necessity of publicity especially on agricultural spraying for the producers.

Key words: Aegean region, viticulture, survey

\section{Giriș}

Dünya nüfusu her geçen gün artış göstermektedir. Artan nüfus ile beraber, beslenme ihtiyacı sorunu ortaya çıkmakta ve bu durum güvenli gıda teminini zorlaştırmaktadır. Günümüz toplumlarının 
en önemli gereksinimlerinden biri güvenilir gıdalara duyulan ihtiyaçtır. Bu ihtiyaç, toplum sağlı̆̆ açısından da önem arz etmektedir.

Gelişmiş ülkelerde, hızla artan dünya nüfusunun gıda ihtiyacını karşılayabilmek amacıyla birim alandan yüksek verim elde etmeye yönelik tarım politikaları ana hedef haline gelmiştir. Yeşil Devrim olarak da adlandırılan bu tarım politikaları doğrultusunda yoğun ve bilinçsiz kimyasal ilaç ve gübre kullanımı önemli artış göstermiştir. Bu olumsuz uygulamalara, yoğun ve yanlış toprak işleme uygulamalarının da eklenmesi ile toprağın fiziksel yapısında bozulmalar, organik maddelerin ve toprak canlılarının yok olması problemleri ortaya çıkmıştır. Tarımda yaşanan bu sürecin sonunda modern tarım olarak nitelendirilen bu teknikler ile tarımsal üretimde yaşanan artışların beklenildiği gibi açlık problemini çözmediği, aksine insan sağlığı ve doğal denge üzerinde olumsuzluklar yarattığının farkına varılmıştır. Uygulanan tarım tekniklerinin yalnız üretim miktarındaki artışla değerlendirilemeyeceği, aynı zamanda çevre, insan ve hayvan sağlığına etkilerinin de incelenmesi gerektiği anlaşılmıştır (Aba Öner ve Işın, 2014). Tarımda karşılaşılan bu olumsuz gelişmeler, tarımsal üretim sürecinin kontrollü olması gereğini ortaya çıkarmıştır. Bu doğrultuda İTU adı verilen alternatif tarımsal üretim modeli ortaya çıkmıştır (Gözen, 2010).

Avrupa'da yaş meyve ve sebze pazarının önemli bir kısmına sahip perakendeciler, EUREP adı altında oluşturdukları bir çalışma grubu ile 1997 yılında bir araya gelmişler ve 1999'da günümüzdeki İTU'nun temelini oluşturan EUREPGAP (Euro Retailer Produce Working Group Good Agricultural Practices) standardını oluşturmuşlardır (Hasdemir, 2011). Birleşmiş Milletler Gıda ve Tarım Örgütü (FAO) tarafindan, 2002 yılı Dünya Sürdürülebilir Kalkınma Zirvesi’nde İTU, tarım ve kırsal kalkınmanın prensiplerinden biri olarak benimsenmiştir. Aynı zamanda FAO, Dünya Ticaret Örgütü üyesi olan ülkelere EUREPGAP standartlarını referans ilke olarak kabul etmelerini önermiştir (Aba Öner ve Işın, 2014). Tüm bu gelişmeler sonrasında, 2007 yılında EUREPGAP ismi standardın tüm dünya ülkeleri tarafından kabul görmesiyle "GLOBALGAP” olarak değiştirilmiştir.

Türkiye'de, Tarım ve Orman Bakanlığı tarafından aynı esaslara dayanan "İyi Tarım Uygulamalarına İlişkin Yönetmelik" 08.09.2004 tarih ve 25577 sayılı Resmi Gazete'de yayınlanmıştır. Bu yönetmelik daha sonra 05.05.2005 ve 15.05.2006 tarihlerinde iki kez değişikliğe uğramıştır. Son olarak yapılan değişikliklerle 07.12.2010 tarih ve 27778 sayılı Resmi Gazete'de yayınlanan "İyi Tarım Uygulamaları Hakkında Yönetmelik" daha kapsamlı bir standart halini almış ve diğer yönetmelik yürürlükten kaldırılmıştır (Anonim, 2017). İTU, tarımsal üretim sistemini sosyal açıdan yaşanabilir, ekonomik açıdan karlı ve verimli, insan sağlığını koruyan, hayvan sağlığı ve refahı ile çevreye önem veren bir hale getirmek için uygulanması gereken işlemleri ifade etmektedir (Anonim, 2017).

Türkiye bağcılık açısından, dünyanın en uygun iklim kuşağı üzerinde yer alması, asmanın anavatanı olan bölgeler arasında olması, eski ve köklü bir bağcılık geçmişine sahip olması, asmanın kültüre ilk alındığı merkez olması ve zengin bir asma genetik potansiyeline sahip olması gibi avantajları nedeniyle dünyada söz sahibi ülkeler arasındadır (Keskin ve ark., 2018). Bağcılık ülke genelinde birçok üreticinin geçim kaynağını oluşturmaktadır (Semerci ve ark., 2015).

Türkiye'de üretilen üzümlerin yaklaşık \%52,1'i sofralık, \%36,6's1 kurutmalık, \%11,3'ü şaraplık ve şıralık olarak değerlendirilmektedir (Çelik, 2018). Ülkemizde üretilen üzümün önemli bir kısmı sofralık olarak tüketilmektedir. Taze olarak değerlendirilen sofralık üzümlerde iri, gösterişli ve bir örnek taneler üzümün pazar değerini arttıran önemli kalite unsurlarındandır (Dardeniz ve ark., 2018). Türkiye, çekirdeksiz üzüm üretimi ve ihracatında da dünyada ilk sıralarda yer almaktadır. Türkiye'de yetiştirilen çekirdeksiz kuru üzümün yaklaşı \%90'1 ihraç edilmektedir (Ünal ve Soltekin, 2018). Kuru üzüm ihracatının büyük bir bölümünün Avrupa Birliği (AB) ülkelerine yapılması nedeniyle, $\mathrm{AB}$ ülkeleri önemli bir çekirdeksiz kuru üzüm pazarı konumundadır. $\mathrm{Bu}$ nedenle $\mathrm{AB}$ ülkeleri tarafından ön koşul olarak kabul edilen, üzüm üretiminde İTU son derece önem arz etmektedir. Türkiye'de Tarım ve Orman Bakanlığı, Bitkisel Üretim Genel Müdürlüğü’nden ulaşılan verilere göre 2017 yılında 328.561 dekar bağ alanında İTU yapıldığ 1 belirtilmektedir. Yine 2017 yılı Bitkisel Üretim Genel Müdürlüğü verilerine göre, bağcılıkta İTU en fazla Manisa ili Salihli ilçesinde yapılmaktadır. Manisa ilinde 2017 yılında 91.981 dekar alanda 1590 üretici bağcılıkta İTU faaliyeti yürütmüştür (Anonim, 2018).

$\mathrm{Bu}$ araştırmada Manisa ili Salihli ilçesi üzüm üreticilerinin geleneksel tarım yöntemlerine göre daha az bilgi sahibi olduğu İTU' ya yönelik bilgi ve bilinç düzeyinin belirlenmesi amaçlanmıştır. 


\section{Materyal ve Yöntem \\ Materyal}

Araştırmada kullanılan materyalin önemli bir bölümünü, Manisa ili Salihli ilçesi, Merkez, Kemerdamları, Poyrazdamları, Adala, Çapaklı, Bektaşlar, Durasıllı, Pazarköy, Çökelek, Süleymaniye, Kabazlı ve Mersinli mahallelerinde üzüm yetiştiriciliği yapan bağcılar ile anket yapılarak elde edilen birincil veriler oluşturmuştur. Örnek kapsamına alınan işletmelere gidilerek bağcılar ile yüz yüze görüşme yapılmak suretiyle anket formları doldurularak, tarım işletmelerinden 2017-2018 üretim dönemine ait veriler toplanmıştır. Elde edilen birincil verilerin yanı sıra konu ile ilgili daha önce yapılmış çalışmalardan elde edilen araştırma bulguları, çeşitli kuruluşların kayıtları ve yayınlanmış olan ikincil verilerinden de yararlanılmıştır.

\section{Yöntem}

Tarım ve Orman Bakanlığı, Bitkisel Üretim Genel Müdürlüğ̈̈ 2017 yılı verilerine göre, Türkiye'de toplam 6.247.107 dekar alanda İTU yönetmeliğine uygun üretim yapılmakta ve bu üretimin 328.561 dekarını üzüm üretimi oluşturmaktadır. Bitkisel Üretim Genel Müdürlügü verilerine göre, 2017 yılında bağcılıkta en fazla İTU yapılan ilin 1590 üretici ile Manisa, Manisa ilinde ise en fazla İTU yapılan ilçenin 150 üretici ile Salihli olduğu belirlenmiştir. Bu nedenlerle çalışma bölgesi olarak Manisa ili Salihli ilçesi seçilmiştir. Salihli ilçesinde "Oransal Örnek Hacmi” yöntemi ile belirlenen 80 üretici ile anket çalışması uygulanmıştır. İTU yapan bağcıların İTU teknikleri hakkındaki bilgi düzeyi, memnuniyet durumu, karşılaş1lan problemler, sunulan çözüm önerileri ve ITTU'nun geleceği hakkındaki düşüncelerine ait veriler, üreticiler ile bire bir yapılan anket çalışmaları yoluyla bulunmuştur. Anket formlarındaki bilgilerin veri girişi SPSS ortamında yapılmıştır. Bilgisayara girilen birincil veriler SPSS programı ile değerlendirilmiştir.

\section{Örnekleme yöntemi ve büyüklüğü}

Ankete katılan üreticilerin belirlenmesinde bütün üreticilerin örnek olma ihtimalinin eşit olması ve örneğe giren üretici sayısının tespit edilmesi amacıyla aşağıdaki 'Oransal Örnek Hacmi' formülü kullanılmıştır (Arıkan, 2007).

$$
n=\frac{N p(1-p)}{(N-1) \sigma_{\hat{p}_{x}}^{2}+p(1-p)}
$$

Formülde;

$$
\mathrm{n}=\text { Örnek hacmi, } \mathrm{N}=\text { Toplam üreticisi sayıs1, } \mathrm{p}=\text { Örneğe girecek üreticilerin oran1, } \sigma_{\hat{p}_{x}}^{2}=
$$
Oranın varyansıdır. Araştırmada maksimum örnek hacmine ulaşılmak istenmiştir. Bu amaçla p: 0.50 ve (1-p):0.50 alınmıştır. Buna göre, araştırma için \%99 güven aralığ 1 ve $\% 10$ hata payı dikkate alınarak toplam 80 üretici ile yüz yüze görüşülmüsşür.

\section{Bulgular ve Tartışma}

Manisa ili Salihli ilçesi, Türkiye bağcılığında üretim miktarı ve ekonomik potansiyeli yönüyle en önemli ilçelerden birisidir. İlçede ihracata yönelik gerçekleştirilen üretimde, Sultani çekirdeksiz çeşidi önemli bir yere sahiptir. Dünyada kuru üzüm ihracatının önemli bir kısmı da Türkiye tarafından gerçekleştirilmektedir. Bu koşullar çerçevesinde, ihracata yönelik bir standart olan İTU'nun bölgedeki üreticiler tarafından bilinmesi ve doğru bir şekilde uygulanması büyük önem arz etmektedir. $\mathrm{Bu}$ araştırmada Manisa ili Salihli ilçesi örnek alınarak, bağcılıkta ITTU sistemini benimseyen üreticilere ait, sosyo-ekonomik özellikler incelenmiştir. Üreticilerin İTU standardı hakkındaki bilgi ve bilinç düzeyi de incelenerek, İTU standardının geleceğine yönelik görüşleri alınmıştır.

Araştırmada, üreticilerin sosyo-ekonomik özelliklerine ilişkin bilgilerin önemli olduğu düşünülmüş ve elde edilen veriler Çizelge 1'de verilmiştir. Yaş durumuna göre üreticilerin \%21.3'ü 40 yaş ve altında iken, \%26,3'ünün 41-50 yaş aras1 ve \%52,4'ünün 51 yaş ve üzerinde olduğu belirlenmiştir. Araştırmada orta yaşlı üreticilerin üretim faaliyetlerinde daha çok yer aldığ görülmüştür (Çizelge 1). Hasdemir (2011) tarafından, Afyonkarahisar ilinde yapılan çalışmada, kiraz üretiminde İTU yapan üreticilerin \%2,94'ü 20-30, \%55,88'i 30-50 yaş arasında, \%41,18'i 50-80 yaş 
arasında olduğu belirlenmiştir. Polat (2017), Mersin ili Silifke ilçesinde yapılan çalışmada İTU yapan üreticilerin yaş ortalamasını 55 olarak belirtmiştir. Pilak (2018), Marmara Bölgesi’nde yürüttüğü çalışmasında, zeytin üretiminde İTU yapan üreticilerin yaş ortalamasını 58.7 olarak belirlemiştir. Engin (2015) tarafından, Antalya ili, Kumluca ilçesinde yapılan çalışmada örtü altı sebze üretiminde ITTU yapan üreticilerin \%21,1'inin 30-39 yaş arasında, \%47,4'ünün 40-49 yaş arasında, \%21,1'inin 5059 yaş arasında, \%10,5'inin ise 60-69 yaş arasında olduğu belirtilmiştir. Bayyiğit (2018) tarafindan, Mardin ilinde zeytin yetiştiriciliğinde İTU potansiyelinin değerlendirilmesi amaçl, zeytin üretiminin en yoğun olduğu bölgelerde çalışma yapılmış ve üreticilerin ortalama yaş1 52.1 olarak belirtilmiştir. $\mathrm{Bu}$ sonuçlar, bu araştırmadan elde edilen sonuçlar ile büyük bir benzerlik göstermektedir. Araştırma kapsamında, üreticilerin cinsiyet dağılımına bakıldığında \%88,7'sinin erkek ve \%11,3'ünün ise kadın olduğu belirlenmiştir.

Çizelge 1. Üreticilerin Sosyo-ekonomik özelliklerine ilişkin bilgiler

\begin{tabular}{|c|c|c|c|c|c|c|c|}
\hline Değişken & Kategori & Say1 & $\%$ & Değișken & Kategori & Say1 & $\%$ \\
\hline \multirow{4}{*}{ Yaş } & $<40$ & 17 & 21,3 & \multirow{4}{*}{ Cinsiyet } & \multirow{2}{*}{ Erkek } & \multirow{2}{*}{71} & \multirow{2}{*}{88,7} \\
\hline & $41-50$ & 21 & 26,3 & & & & \\
\hline & $>51$ & 42 & 52,4 & & Kadın & 9 & 11,3 \\
\hline & Toplam & 80 & 100,0 & & Toplam & 80 & 100,0 \\
\hline Değişken & Kategori & Sayı & $\%$ & Değişken & Kategori & Say1 & $\%$ \\
\hline \multirow{5}{*}{ Eğitim } & İlkokul & 38 & 47,5 & \multirow{4}{*}{$\begin{array}{c}\text { Arazi } \\
\text { varlığı } \\
\text { (da) }\end{array}$} & 0-100 dekar & 67 & 83,7 \\
\hline & Ortaokul & 4 & 5,0 & & $\begin{array}{l}\text { 101-250 } \\
\text { dekar }\end{array}$ & 11 & 13,8 \\
\hline & Lise & 22 & 27,5 & & $\begin{array}{l}250 \text { dekar ve } \\
\text { üzeri }\end{array}$ & 2 & 2,5 \\
\hline & Üniversite & 16 & 20,0 & & Toplam & 80 & 100,0 \\
\hline & Toplam & 80 & 100,0 & & & & \\
\hline Değişken & Kategori & Say1 & $\%$ & & & & \\
\hline \multirow{3}{*}{ Gelir (TL) } & $\begin{array}{l}\text { Orta (Asgari } \\
\text { ücret) }\end{array}$ & 29 & 36,3 & & & & \\
\hline & $\begin{array}{l}\text { Yüksek (Asgari } \\
\text { ücret üzeri) }\end{array}$ & 51 & 63,7 & & & & \\
\hline & Toplam & 80 & 100,0 & & & & \\
\hline
\end{tabular}

Araştırmada üreticilerin eğitim durumları incelendiğinde, okuma yazma bilmeyen üretici olmadığı, üreticilerin \%47,5'inin ilkokul, \%5'inin ortaokul, \%27,5' inin lise, \%20' sinin ise üniversite mezunu olduğu belirlenmiştir. Gücüyen (2007) tarafindan, Manisa ilinde yürütülen bir çalışmada 50 üretici ile anket yapılmış ve 17 ilkokul, 19 orta dereceli okul ve 14 üreticinin üniversite mezunu olduğu belirlenerek, üreticilerin eğitim durumunun yüksek olduğu saptanmıştır. Hasdemir (2011), Afyonkarahisar'da kiraz üretiminde ITTU yapan üreticilerin, \%5,88'inin okuryazar, \%29,41'inin ilkokul mezunu, \%32,35'inin ortaokul mezunu, \%29,41'inin lise mezunu ve \%2,94'ünün üniversite mezunu olduğunu bildirmiştir. Pilak (2018) ise, zeytin üretiminde İTU yapan üreticilerin \%57,4'ünün ilkokul, \%19,05'inin lise, \%22,2'sinin üniversite mezunu olduğunu belirtmiştir. Bu araştırmalar İTU standardını benimseyen üreticilerin eğitim seviyesinin genel olarak orta ve üzeri olduğunu göstermektedir. $\mathrm{Bu}$ araştırmada incelenen üreticilerin gelir durumlarında ise, düşük gelirli üreticinin olmadığ1 ve üreticilerin büyük çoğunluğunun $(\% 63,7)$ yüksek gelir sahibi olduğu görülmüştür. Üreticilerin arazi varlığ incelendiğinde, \%83,7' sinin 0-100 dekar arasında arazi varlığına sahip oldukları olduğu görülmüştür. Benzer araştırmalarda, Pilak (2018), zeytin üretiminde İTU yapılan alanlarda, bahçelerin genelde 60-65 dekar büyüklüğünde olduğunu belirtmiştir.

Araştırmada ayrıca Manisa ili Salihli ilçesinde İTU yapan üreticilerin, İTU hakkındaki bilgi düzeyleri, İTU'dan anladıkları kavram, İTU'ya başlama kararları, İTU'ya geçme sebepleri ve İTU sistemindeki tecrübeleri incelenmiştir. Araştırma kapsamında incelenen üreticilerin büyük çoğunluğu $(\% 48,94)$ İTU'dan güvenli ve sağlıklı gıda üretimi ifadesini anladığını belirtmiştir. Benzer şekilde, yeni bir teknik, doğayı koruyan tarım, sertifikalı ürün, şeklinde İTU'nun önemine vurgu yapan geri dönüşler alınmıştır. Üreticilerin \%69,2'si yeni ve farklı bir tarım tekniği denemek için İTU'ya geçmenin önemli olduğunu, \%54,1'i sağl1k, \%47,4'ü ekonomik, \%22,6's1 çevre koruma faktörlerinin 
önemli olduğunu düşünerek İTU'yu tercih ettiğini ifade etmişlerdir. Üreticilerin \%26,7'lik bir bölümü ise sadece destek almak için İTU'nun önemli olduğunu belirtmiştir. Hasdemir (2011), Afyonkarahisar kiraz üreticilerinde İTU'nun benimsenmesini etkileyen faktörleri; \%66,8 sağlık faktörleri, \%45,59 çevre koruma faktörleri ve $\% 25$ yeni ve farklı şeyleri deneme isteği olarak belirlemiştir. Benzer şekilde Pilak (2018), zeytin üreticilerinin İTU'ya geçme nedenleri arasında ilk sırada ekonomik faktörler ve sağlık faktörlerinin olduğunu tespit etmiştir. Bu sonuçlar, araştırma bulgularımızı destekler niteliktedir.

ITU hakkında bilgiye erişim noktasında, üreticilerin $\% 96,8$ 'i Tarım ve Orman İl-ìlçe Müdürlüğü, tarım danışmanları, üretici birlikleri ve üniversitelerden bilgi aldığını ifade ederken; \%3,2'si komşudan, televizyondan, reklamlardan bilgi aldığını belirtmiştir. Üreticilerin büyük çoğunluğunun, teknik yeterliliği olan kişilerden bilgi almayı tercih ettiği görülmüştür. Engin (2015), Antalya ili, Kumluca ilçesinde yapılan çalışmada, örtü altı sebze üretiminde İTU yapan üreticilerin, arazi genişliğinin artması ile beraber bilgi kaynağı olarak Tarım İl-i̇lçe Müdürlüğü’nden yararlanma durumunun arttığını belirtilmiştir. Hasdemir (2011) ise, İTU yapan üreticilerin ITTU'yu ilk duydukları kaynağın \%75 ihracatçılar, \%13,4 tarım ilçe müdürlüğü, \%11,76 basın kuruluşları olduğunu belirtmiştir.

Manisa ili Salihli ilçesinde İTU yönetmeliğine uygun üretim yapan üreticilerin, İTU kontrol noktaları hakkındaki bilgi seviyeleri ve İTU tekniklerinin uygulanması konusundaki davranışları, araştırmanın önemli bir bölümünü oluşturmuştur. Araştırma sonuçlarına göre, üreticilerin \%998,7'sinin toprak analizi yaptırdığ $1, \% 1,3$ 'ünün ise toprak analizi yaptırmadığı görülmüştür. İTU standardında belirtilen risk analizlerinde, özellikle gübreleme kararı verileceği zaman üreticilerin toprak analizi yaptırmaları gerekliliği bulunmaktadır. Araştırma sonuçları İTU sisteminde bulunan üreticilerin toprak analizi yaptırılması konusunda bilinçli olduklarını göstermiştir. Buna karşı1ık, Hasdemir (2011) tarafından kirazda İTU çalışmasında, İTU yapan üreticilerin \%58,09' unun toprak analizi yaptırdığ1 belirlenmiştir. Benzer şekilde Gücüyen (2017) tarafından Manisa ilinde bağcılığın yoğun yapıldığı ilçelerde anket çalışması yapılmış ve üreticiler içinde her yıl toprak analizi yaptıranların oranı \%34 iken, toprak analizi yaptırmayanların oranı \%38 olarak belirtilmiştir. Bayyiğit (2018), Mardin ilinde konvansiyonel zeytin üretimi yapan üreticiler ile anket yapılmış ve ankete katılanların \%5, i toprak analizini yaptırdığını \%95' i ise toprak analizini yaptırmadığını belirtmiştir. Bu araştırma sonuçları, bağcılıkta ITTU standardına uygun üretim yapan üreticilerin toprak analizi yaptırma konusunda daha bilinçli olduğunu göstermektedir.

Üreticilerin gübrelemeyle ilgili tavsiye aldığı kaynaklar incelendiğinde, $\% 33,8$ ' i toprak ve bitki analizi sonucu tavsiyesine göre, \%3,2'si Tarım ve Orman İl ve İlçe Müdürlüğü tavsiyesi ile $\% 26,8$ ' i ziraat mühendisi tavsiyesine göre, \%15,2'si kendi tecrübesine göre, \%12,1'i Ziraat Odas1 tavsiyesine göre, $\% 8,9^{\prime}$ u ilaç gübre bayisinin tavsiyesine göre gübrelemeye karar verdiğini belirtmiştir.

Araştırma kapsamında, üreticilerin $\% 97,5$ ' i su analizi yaptırırken, sadece $\% 2,5$ ' inin su analizi yaptırmadığ1 görülmüştür. Buna karşılık Hasdemir (2011), İTU yapan üreticilerin \%25' inin su analizini yaptırdığını belirtmiştir. Pilak (2018) ise, üreticilerin \%73' ünün su analizini yaptırdığını belirlemiştir. 2011 yılında gerçekleştirilen araştırmada su analizi yaptıranların oranı \%25 olarak bulunurken (Hasdemir, 2011), 2018'de \%73 (Pilak, 2018) ve bu araştırmada \%97,5 olarak bulunmas1, ITU yapan üreticilerin su analizi konusunda daha fazla bilinç kazandığınına dair bir bulgu olarak değerlendirilebilir.

ITTU standardında, bitki koruma uygulamalarına ayrı bir önem verilmektedir. Araştırmada, ilaçlama ile ilgili üreticilerin hastalık ve zararlı mücadelesinde uygulamış oldukları öncelikli mücadele yöntemleri incelenmiştir. Araştırmada bağlarda en fazla görülen hastalıklar sırasıyla \%75,3 ve \%71,2 ile mildiyö ve külleme hastalıkları olarak ortaya çıkmıştır. Benzer şekilde, üreticilerin büyük çoğunluğu bağa en fazla zarar veren hastalıkların külleme ve mildiyö olduklarını belirtmişlerdir. Üreticilerin hastalık mücadelesinde mildiyö hastalığ için \%56,7 kimyasal mücadele, \%31,3 kültürel mücadele, \%12 fiziksel mücadele uyguladığı görülmüştür. Külleme hastalığ 1 için, \%53,2 kimyasal mücadele, \%31,9 kültürel mücadele, \%14,9 fiziksel mücadele uygulandığı belirlenmiştir. Kurşuni küf ve ölü kol hastalıkları için de benzer sonuçlar elde edilmiştir. Bu hastalıkların hiç birisinde koruma önlemi olarak biyolojik mücadele yöntemi tercih edilmediği tespit edilmiştir (Çizelge 2). 
Çizelge 2. Bağlarda karşılaşılan hastalıklar ile öncelikli mücadele yöntemleri (\%)

\begin{tabular}{|l|c|c|c|c|c|c|}
\hline Hastalı̆̆ın Adı & Kültürel & Biyolojik & Biyoteknik & Kimyasal & Fiziksel & Toplam \\
\hline Mildiyö & 31,3 & 0,0 & 0,0 & 56,7 & 12,0 & 100,0 \\
\hline Külleme & 31,9 & 0,0 & 0,0 & 53,2 & 14,9 & 100,0 \\
\hline Kurşuni Küf & 8,4 & 0,0 & 0,0 & 58,3 & 33,3 & 100,0 \\
\hline Ölü Kol Hastalığı & 25,0 & 0,0 & 0,0 & 75,0 & 0,0 & 100,0 \\
\hline
\end{tabular}

ITTU standardına uygun yapılan üretimde, bağda hastalıklarla mücadelede ilk olarak kültürel tedbirlerin alınması, sonra mekanik mücadele, biyoteknik mücadele ve biyolojik mücadele yöntemlerinin uygulanması tercih edilmektedir. Kimyasal mücadele son olarak başvurulması gereken mücadele yöntemi olarak belirlenmiştir. İTU standardının aksine araştırma bulgularına göre kimyasal mücadele tercih edilen ilk mücadele yöntemi olmuştur. Bu durum, üreticilerin bağlarda karşılaştıkları hastalık mücadelesi yöntemleriyle ile ilgili bilgi seviyelerinin yetersiz olduğunu göstermektedir. Benzer sonuçlar Engin (2015) tarafindan, örtü altı sebze üretiminde İTU yapan üreticilerin kimyasal ilaç kullanımı konusundaki davranışlarında ortaya çıkmıştır.

Çizelge 3. Bağlarda karşılaşılan ana zararlılar ile öncelikli mücadele yöntemleri (\%)

\begin{tabular}{|l|l|l|l|l|l|l|}
\hline Zararlının Adı & Kültürel & Biyolojik & Biyoteknik & Kimyasal & Fiziksel & Toplam \\
\hline Salkım Güvesi & 9,4 & 1,4 & 33,4 & 50,0 & 5,8 & 100,0 \\
\hline Unlu bit & 0,0 & 0,0 & 0,0 & 100,0 & 0,0 & 100,0 \\
\hline Trips & 0,0 & 0,0 & 0,0 & 100,0 & 0,0 & 100,0 \\
\hline
\end{tabular}

Araştırmada, bağda en fazla görülen zararlı \%91,2 ile salkım güvesi olarak ortaya çıkmıştır. Üreticilerin zararlı mücadelesinde, salkım güvesi için \%50 kimyasal mücadele, \%33,4 biyoteknik mücadele, $\% 9,4$ kültürel mücadele, $\% 5,8$ fiziksel mücadele, $\% 1,4$ biyolojik mücadele uyguladığ1 görülmüştür. Unlu bit ve trips zararlıları için \%100 kimyasal mücadele tercih edilmiş olup, kültürel mücadele, biyolojik mücadele, biyoteknik mücadele ve fiziksel mücadele tercih edilmemiştir. Engin (2015), örtü altı sebze üretiminde, İTU yapan üreticilerin, yaprak biti zararlısı için \%100'ünün kimyasal mücadele gerçekleştirdiğini bildirmiştir. Aynı araştırmada Trips zararlısı için, \%63,7 kimyasal mücadele, \%27,3 biyoteknik mücadele, \%9 kültürel mücadele uygulanırken, konvansiyonel üretim yapan üreticilerde bu oranların; \%64,5 kimyasal mücadele, $\% 21,9$ biyoteknik mücadele, $\% 13,6$ biyolojik mücadele olarak gerçekleștirdiği belirtilmiştir. Araştırma bulguları, hastalık ve zararlı mücadelesinde tercih edilen ilk koruma yönteminin kimyasal mücadele olduğunu ortaya koymuştur. Bağ üreticilerinin entegre mücadele konusunda yeterli bilgi ve deneyime sahip olmadıları görülmüştür. Benzer sonuçlar, Özercan (2012) tarafından, İzmir ili süs bitkileri yetiştiriciliğinde İTU potansiyelinin değerlendirildiği çalışmada görülmüştür. Üreticilerin \%6's1 entegre mücadeleyi tanımlarken, \%94'ü entegre mücadelenin ne anlama geldiğini bilmediklerini ifade etmişlerdir.

ITTU, üreticilerin ilaçlamayla ilgili teknik yeterliği olan kişilerden tavsiye almasını belirtmektedir. İlaçlamayı yapacak olan kişinin konuyla ilgili eğitime tabi tutulması gerekliliği de İTU kontrol noktalarında belirtilmiştir. Araştırma bulgularına göre, üreticilerin çok küçük bir bölümü $(\% 5,5)$ tavsiye almadığını belirtmekte, üreticilerin büyük çoğunluğu $(\% 94,5)$ ise ilaçlama tavsiyesini teknik yeterliliği olan kişi, kurum ve kuruluşlardan aldığını bildirmektedir. Hasdemir (2011) kiraz üretiminde İTU yapan üreticilerin \%94,12'si Tarım İlçe Müdürlügü'nün tavsiyesine göre ilaçlama tarihine karar verirken, $\% 4,41$ 'i ilaç bayisinin tavsiyesi ile $\% 1,47$ ' si ise üreticinin kendi tecrübesi ile ilaçlamaya karar verdiği belirtilmiştir. Bu sonuçlar ilaç tavsiyesi konusunda, İTU yapan üreticilerin bilgi düzeyinin yüksek olduğunu göstermektedir.

ITU standardına göre, kullanılacak olan ilaçların ürüne ruhsatlı olması birinci derece kontrol noktasıdır. İlaçların mutlaka ürüne ruhsatlı olması gerekmektedir. Araştırma sonuçlarına göre, üreticilerin tamamı (\%100) Bitki Koruma Ürünlerinin (BKÜ) seçiminde ürüne ruhsatlı olmasına dikkat ettiklerini belirtmişlerdir. İlaçlamayı yapacak olan kişinin, BKÜ uygulama yetki belgesinin olması, İTU'da yine birinci derece kontrol noktaları arasında bulunmaktadır. Araştırma sonuçlarımıza göre, ankete katılan üreticilerden $\% 98,8$ ' inin bu belgeye sahip olduğu görülürken, yalnızca $\% 1,2$ 'sinde BKÜ uygulama yetki belgesi bulunmadığı görülmüştür. Bu araştırma sonuçlarından farklı 
olarak Özercan (2012) çalışmasında, üreticilerin \%83'ünün BKÜ uygulayan kişilerin yetki belgesi olmadan uygulama yaptıkları belirtilirken, \%17'sinin BKÜ uygulama yetki belgesinin olduğu ifade edilmiştir.

İşçi sağlığı ve güvenliği İTU standardının önemli kontrol noktaları arasında yer almaktadır. Bu noktada kimyasal ilaçların kullanımı sırasında insan sağlı̆̆ını tehlikeye sokan her bir riskin tedbirinin alınması gerekmektedir. Tedbir amaçlı giyilmesi gereken koruyucu kıyafet ve ekipmanlar, İTU'nun birinci derece kontrol noktaları içerisinde yer almaktadır. Araştırma sonuçlarına göre üreticilerin yarısından fazlası $(\% 57,6)$ koruyucu kıyafetlerini tam olarak giymediğini belirtirken, \%42,4'lük kısmı koruyucu kıyafet giydiğini belirtmiştir. Bu durumda, üreticilerin koruyucu kıyafet ve ekipmanlar konusunda yeterli bilince sahip olmadıkları ya da konuya karşı yeterli duyarlılığı göstermedikleri söylenebilir. Benzer şekilde Gücüyen (2017), Manisa ilinde konvansiyonel üretim yapan üreticiler içerisinde, üreticilerin \%42'sinin insan sağlığını etkileyen maddelere karşı hiçbir önlem almadığ1, \%58'inin ise sadece maske kullandığı belirtilmiştir. Özercan (2012), üreticilerin ve çalışanların \%33'ünün kimyasal uygulamalarda koruyucu kıyafet ve ekipmanları kullandığı, \%67'sinin koruyucu kıyafet ve ekipman kullanılmadığı belirtmiştir. $\mathrm{Bu}$ çalışmaların sonuçları, yapılan bu araştırma sonuçlarını destekler niteliktedir.

ITTU boş bitki koruma kaplarının imhasının, insan ve çevreye zarar vermeyecek şekilde yapılması gerektiğini belirtmektedir. Araştırma sonuçlarına göre, üreticilerin büyük çoğunluğu $(\% 98,7)$ boş tarım ilacı ambalajlarını ağızı kilitli, metal varillerde toplayıp yakarak imha ettiklerini ifade etmiştir. Hasdemir (2011), üreticilerin \%61,76' sının boş tarım ambalajlarını yakarak imha ettiğini, \%4,41'inin çöpe attığını, \%7,35'inin toprağa gömerek imha ettiğini, \%1,47'sinin ilaç bayisine geri teslim ettiğini, \%25'inin ise toplama merkezine teslim ettikleri bildirmektedir. Özercan (2012) araştırmasında, ankete katılan tüm üreticilerin boş bitki koruma maddelerinin ambalajlarını yakarak imha ettikleri belirtmiştir. Tüm bu araştırma sonuçları birbirini destekler niteliktedir. Üretimde uygulanan son ilaçlama ile hasat arasındaki bekleme süresi İTU standardında birinci dereceden kontrol noktaları arasında bulunmaktadır. Çalışma sonuçlarına göre, üreticilerin büyük çoğunluğu $(\% 98,7)$ hasat öncesi bekleme süresini belirlerken, etikette yazan talimata uyulduğunu bildirmiştir. Bu sonuçlar üreticilerin konu hakkında yeterli bilgi ve bilinç düzeyine sahip olduklarını göstermektedir.

Hasat edilen üründe maksimum kalıntı limiti (MRL), Türkiye'deki mevzuatta yasal olarak bulunmasına izin verilen en yüksek pestisit kalıntı limitidir. İTU'ya göre üretici veya üreticinin müşterisinde ürünün satılması düşünülen pazarla ilgili uygulanabilir mevcut MRL listeleri bulunmalıdır. Maksimum kalıntı limiti ile ilgili uygulanması gereken noktalar, İTU standardında birinci dereceden kontrol noktaları arasında sorgulanmaktadır. Araştırma sonucuna göre, üreticilerin \%45'i maksimum kalıntı limiti hakkında bilgi sahibi olduğunu ifade ederken, \%55'i konu hakkında bir fikrinin olmadığını belirtmiştir. Araştırma sonuçları, üreticilerin tamamının (\%100) son üründe kalıntı analizi yaptırdığını göstermiştir. İTU standardına göre kalıntı analizi yapılan laboratuvarların TS EN ISO/IEC 17025 standardına göre akredite olması gerekmektedir. Araștırmada kalıntı analizinin yaptırıldığ l laboratuvarların TS EN ISO/IEC 17025'e göre akreditasyonunun mevcut olduğu görülmüştür. İTU üretim sisteminde, kalıntı analizi sonucunda izin verilen limit üstü aktif madde ile karşılaşılması durumu, birinci dereceden kontrol noktası olup, bu duruma izin verilmemektedir. Araştırma sonuçlarına göre, limit üstü aktif madde ile karşılaşılması durumunda üreticilerin $\% 97,5$ ' $\mathrm{i}$ ürünleri imha edeceğini, ürünü pazara sunmaktan vazgeçeceğini, pazara sunacak ise ürünü konvansiyonel olarak değerlendireceğini belirtmiştir. Ancak, üreticilerin $\% 2,5$ 'i ürünü kendisi tüketeceğini ifade etmişlerdir. Benzer şekilde, Engin (2015) tarafından örtü altı sebze üretiminde İTU yapan üreticilerin tamamı (\%100) limit üstü aktif madde ile karşılaşma durumunda ürünlerini imha ettiklerini belirtmişlerdir. Üretilen ürünlerin pazarlanması üreticiler için önemli olup, anket sonuçlarına göre İTU ile yetiştirilen kuru üzümün ortalama satış fiyatı 4,1 TL/kg olarak belirlenmiştir. Üreticiler tarafından, bu fiyatın yetersiz olduğu ve ürünlerini normal konvansiyonel üretim yapan üreticilerden farklı fiyatta satamadıkları bildirilmiştir. Benzer sonuçlar, Hasdemir (2011) tarafından yürütülen çalışmada da bulunmuştur. Hasdemir (2011) tarafindan, kiraz üretiminde İTU yapan ve İTU yapmayan üreticilerin ürün satış fiyatlarına ait değerlerin değişiklik göstermediği belirtilmiştir. ITU yapan üreticilerin ortalama satış fiyatı $2,75 \mathrm{TL} / \mathrm{kg}$ iken, İTU yapmayan üreticilerin ortalama satış fiyatının $2,43 \mathrm{TL} / \mathrm{kg}$ olduğu ifade edilmiştir. Ankete katılan üreticilerin dış piyasaya yönelik hedef pazarı İTU yapanlarda \%88,24 iken, İTU yapmayanlarda ise \%13,24 olduğu belirtilmiştir. Pilak 
(2018) tarafindan, zeytin üretiminde İTU yapan üreticilerin zeytinleri, pazarda farklı fiyatta satılamadığından, İTU'ya olan ilginin artmadığı sonucuna varılmıştır. Polat (2017), Mersin ili Silifke ilçesinde yürüttüğü çalışmada, İTU'nun pazarlama olanaklarına olumlu yönde etkisinin olduğu, ancak yeterli katkıyı sağlayamadığı sonucuna ulaşmıştır.

Tarımsal desteklemeler ile ilgili, üreticilerin \%83,7' si verilen desteğin yeterli olmadığını ifade etmiş olup, desteğin artması yönünde görüş bildirmiştir. Çevresel Amaçlı Tarım Arazilerinin Korunması (ÇATAK) Programı kapsamında, anket yapılan İTU üreticilerinin \%95,6'sı bu destekten memnun olduklarını ifade etmiştir. Polat (2017)tarafından yapılan çalışmada üreticiler ÇATAK desteğinin İTU yapılmasında etkili olduğunu ifade etmişlerdir.

Araştırma sonuçlarına göre, İTU'ya geçen üreticilerin büyük çoğunluğu $(\% 72,5)$ sosyal yaşam alanlarında düzelme olduğu ifade etmiştir. Hasdemir (2011) tarafindan, İTU yapan üreticilerin işletmelerinde temiz suya ulaşma olanağının daha yüksek olduğu tespit edilmiştir. İTU yapan işletmelerde tuvalet varlığının daha çok olduğu belirtilmiştir. İTU yapmayan işletmelerin \% 7,5 'inde banyo-duş imkanı varken, İTU yapan işletmelerin \%10,29'unda banyo-duş imkanı bulunduğu belirtilmiştir. Bu sonuçlar araştırma bulgularını destekler niteliktedir.

Üreticilerin \%96,2'si İTU ile yetişen ürünün sağl1klı olduğu düşünürken, \%3,8'si sağlıklı olduğunu düşünmemektedir. Üreticilerin \% 93,7'si İTU'dan memnun olduğunu ifade ederken, \%6,3'ü memnun olmadığını belirtmiştir. Üreticilerin \%97,5'i İTU'ya devam etmeyi düşünürken, \%2,5'i vazgeçmeyi düşünmektedir.

\section{Sonuç ve Öneriler}

Manisa ili Salihli ilçesinde üzüm üreticilerinin İTU faaliyetleriyle ilgili bilgi düzeyinin incelenmesi amaçlı yapılan çalışmada, üreticilerin genel anlamda İTU standartlarına yönelik olarak bilgi düzeyinin yeterli olduğu görülmüştür.

ITU standardına uygun üretim yapan üreticilerin eğitim seviyesi büyük oranda ortaokul ve üzeri olarak tespit edilmiştir. Üreticilerden \%20'sinin üniversite mezunu olduğu belirlenmiştir. İTU standartlarının gereklilikleri olarak ortaya çıkan su ve toprak analizi gibi konularda Manisa ili Salihli ilçesinde İTU yapan bağcıların tamamına yakınının su ve toprak analizi yaptırdığı ortaya çıkmıştır.

İTU standardında BKÜ ve bitki koruma uygulamalarına yönelik kontrol noktaları önemli bir yer tutmaktadır. Manisa ili Salihli ilçesi örneğinde İTU'ya uygun üretim yapan üreticilerin ruhsatlı ilaç kullanma ve ilaçlama uygulama belgesine sahip olma konularında \%100'e yakın bir bilgi düzeyine sahip olduğu görülmüştür. Benzer şekilde hasat öncesi bekleme sürelerine de üreticilerin çok yüksek oranda uyum sağladıkları görülmüştür. İnsan sağlığı için son derece önemli olan ilaç kalıntısı ve kalıntı analizleri konusunda da üreticilerin bilgi düzeyleri yeterli bulunmuştur.

Araştırma sonuçları, İTU yapan üreticilerin büyük bir çoğunluğunun koruyucu kıyafet ve ekipman kullanımı konusunda yeterli bilgi düzeyine sahip olmadıklarını göstermiştir. Bu sorunun giderilebilmesi içim İTU yapan üreticilere yönelik bilgilendirme çalışmalarının yapılması gerekmektedir.

ITTU uygulayan üreticilerin önemli bir kısmı İTU standardının öneminin giderek artacağını belirtirken, üreticilerin \%22,5'i İTU'nun zorunlu hale geleceği şeklinde fikir beyan etmişlerdir. ITTU insan sağlı̆̆ını koruyan, sosyal açıdan yaşanabilir, çevreyi ve doğal yaşamı önemseyen, tarımda izlenebilirlik ve sürdürülebilirliğin sağlandığı bir üretim sistemidir. $\mathrm{Bu}$ yüzden, İTU'nun yaygınlaştırılması son derece önemlidir. Araştırmada İTU'nun yaygınlaştırılması için en fazla dile getirilen konu İTU ve konvansiyonel yöntemlerle üretilen ürünler arasındaki satış fiyatı farkının belirgin hale gelmesidir. Aynı zamanda, tarımsal desteklerin artırılarak devam etmesinin İTU'nun geleceği açısından önemli olduğu söylenebilir. Bu çalışmanın önemli bir boyutu da İTU ile üretilen üzümlerin ihracatı konusudur. Türkiye çekirdeksiz üzüm üretiminde ve ihracatında dünyada ilk sıralarda yer almaktadır ve kuru üzüm ihracatında $A B$ önemli bir pazar konumundadır. Dolayısı ile, ITU ile üretilen kuru üzümlerin ihracatında $A B$ 'nin istediği gerekliliklerinin sağlanması Türkiye açısından çok önemlidir.

Son söz olarak, tüketicilerin İTU ile üretilen ürünlere yönelik tercihte bulunabilmesi için bu konuda bilgilendirme çalışmalarının yapılması yararlı olacaktır. Böylece, tüketicilerin istediği daha sağlıklı ürün talebinin sağlanması ile İTU'nun sürdürülebilirliğine katkıda bulunulabilir.

Not: Bu makale, Özlem Alemdar'ın Yüksek Lisans çalışmasından üretilmiştir. 


\section{Kaynaklar}

Aba Öner, G., Işın, Ş., 2014. Dünyada ve Türkiye'de İyi Tarım Uygulamalarının Gelişimi. 11. Ulusal Tarım Ekonomisi Kongresi. 3-5 Eylül 2014, Samsun.

Anonim, 2017. url:https://www.tarimorman.gov.tr/Konular/Bitkisel-Uretim/Iyi-Tarim-Uygulamalari Erişim Tarihi: 20.11 .2017

Anonim, 2018. BÜGEM 69500404 -160.02-E.580987 sayı 23.02.2018 tarihli yazısı. 'İyi Tarım Uygulamaları'.

Arıkan, R., 2007. Araştırma Teknikleri ve Rapor Hazırlama. 6.baskı, ISBN:975-8784-35-8. Ankara

Bayyiğit, İ., 2018. Mardin ili zeytin yetiştiriciliğinde İyi Tarım Uygulamaları potansiyelinin değerlendirilmesi. Harran Üniversitesi Fen Bilimleri Enstitüsü, Bahçe Bitkileri Anabilim Dalı Yüksek Lisans Tezi. 94 s.

Çelik, H., 2018. Dünya sofralık üzüm üretimi ve ticareti. Yalova Atatürk Bahçe Kültürleri Merkez Araştırma Enstitüsü Dergisi. 47(1): 11-22.

Dardeniz, A., Gündoğdu, M.A., Akçal, A., Sarıyer, T., Atik, F., Harput, N., 2018. Yalova çekirdeksizi üzüm çeşidinin yazlık sürgünlerinde farklı tepe alma uygulamalarının yıllık dal ile üzüm verim ve kalitesine etkileri. ÇOMÜ Zir. Fak. Derg. 6(1): 51-59.

Engin, Ö.F., 2015. Geleneksel üretim yönteminden İyi Tarım Uygulamalarına geçiş yapan örtüaltı üreticilerinde zararlı yönetimi yönünden olası davranış değiş̧ikliklerinin belirlenmesi: Antalya İli Kumluca İlçesi örneği. Ankara Üniversitesi Fen Bilimleri Enstitüsü, Bitki Koruma Anabilim Dalı Yüksek Lisans Tezi. $166 \mathrm{~s}$.

Gücüyen, A., 2007. Manisa ili ve çevresinde bağcılıkta mekanizasyon durumu, sorunları ve İyi Tarım Uygulamalarına yönelik çözüm önerileri. Ege Üniversitesi Fen Bilimleri Enstitüsü, Tarım Makinaları Anabilim Dalı Yüksek Lisans Tezi. $146 \mathrm{~s}$.

Gözen, H., 2010. Seracılık üretimi faaliyetlerinde İyi Tarım Uygulamaları: Kıbrıs Magosa Örneği. Namık Kemal Üniversitesi Fen Bilimleri Enstitüsü, Tarım Ekonomisi Anabilim Dalı Yüksek Lisans Tezi. 160 s.

Hasdemir, M., 2011. Kiraz yetiştiriciliğinde İyi Tarım Uygulamalarının benimsenmesini etkileyen faktörlerin analiz. Ankara Üniversitesi Fen Bilimleri Enstitüsü, Tarım Ekonomisi Anabilim Dalı Doktora Tezi. 209 s.

Keskin, N., Kunter, B., Alaeddinoğlu, F., 2018.Van ve Yöresinin Atasal Çeşidi Erciş Üzümünün Agroturizm Değeri. II. Uluslararası Batı Asya Turizm Araştırmaları Kongresi. 27-30 Eylül 2018, Van.

Özercan, E., 2012. İzmir İli Süs Bitkileri Yetiştiriciliğinde İyi Tarım Uygulamaları potansiyelinin değerlendirilmesi. Ege Üniversitesi Fen Bilimleri Enstitüsü, Bahçe Bitkileri Anabilim Dalı Doktora Tezi. $165 \mathrm{~s}$.

Pilak, C., 2018. Zeytinde İyi Tarım Uygulaması Yapan üreticilerin yetiştiriciliğe karşı eğilimlerinin araştırılması. Akdeniz Üniversitesi Fen Bilimleri Enstitüsü, Bahçe Bitkileri Anabilim Dalı Yüksek Lisans Tezi.

Polat, K., 2017. Ramsar Alanlarda iklim değişikliği ile mücadele ve uyum açısından İyi Tarım Uygulamalarının rolü: Göksu Deltası örneği. Ankara Üniversitesi Fen Bilimleri Enstitüsü, Tarım Ekonomisi Anabilim Dalı Doktora Tezi. 252 s.

Semerci, A., Kızıltuğ, T., Çelik, D.A., Kiracı, A.M., 2015. Türkiye bağcılığının genel durumu. Mustafa Kemal Üniversitesi Ziraat Fakültesi Dergisi. 20(2): 42-51

Ünal, A., Soltekin, O., 2018. Dünya kurutmalık üzüm üretimi ve ticareti. Yalova Atatürk Bahçe Kültürleri $\begin{array}{lllll}\text { Merkez } & \text { Araştırma } & \text { Enstitüsü } & \text { Dergisi. } & \text { 47(1): }\end{array}$ 